\title{
Venous malformation in the infratemporal fossa diagnosed by CT-guided core needle biopsy
}

\author{
Masato Nagaoka, Tsunetaro Morino
}

Department of

Otorhinolaryngology, Jikei University School of Medicine, Minato-ku, Japan

\section{Correspondence to} Dr Masato Nagaoka; m.nagaoka@jikei.ac.jp

MN and TM contributed equally.

Accepted 3 March 2021

Check for updates

(C) BMJ Publishing Group Limited 2021. No commercial re-use. See rights and permissions. Published by BMJ.

To cite: Nagaoka M,
Morino T. BMJ Case
Rep 2021;14:e238171.
doi:10.1136/bcr-2020-
238171

\section{DESCRIPTION}

A 77-year-old woman presented at the otorhinolaryngology department with left maxillary sinusitis. She reported having discomfort in her throat with no other symptoms. Her medical history included Parkinson's disease, breast cancer, kidney stones but no vascular malformations. Her regular medications were biperiden ( $2 \mathrm{mg} /$ day) and levodopa (150 $\mathrm{mg} /$ day). There was neither palpable endobuccal mass nor paresthesia. CT revealed an incidental 23-mm-diameter mass, a mild lesion, at the right temporal fossa (figure 1A,B). The mass at the right temporal fossa was low in T1-weighted MRIs, high in short tau inversion recovery images, with gradual contrast effect in T1 dynamic contrast-enhanced images (figure 1C,D).

Differential diagnoses included malignant lymphoma, neurogenic tumour and salivary gland tumour. CT-guided core needle biopsy (CNB) was performed because the lesion was impalpable and visualisation of the acoustic window by ultrasound was limited. An interventional radiologist performed a CNB with an 18-gauge semiautomatic needle (FINECORE, Japan) under local anaesthesia (figure 2A,B). Since a slight haematoma was observed immediately after the puncture, the puncture site was pressed, so that it should not deteriorate. The patient was discharged the next day. Histological examination revealed vascular

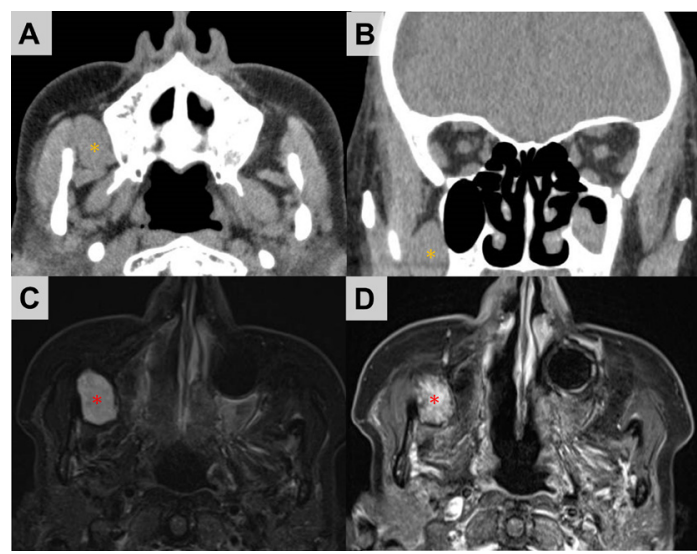

Figure $1 \mathrm{CT}$ and MRI images. (A) CT axial view: a mass with a well-defined border and density equal to that of muscles. (B) CT coronal view: a mass with a welldefined border and density equal to that of muscles. (C) MRI (short tau inversion recovery) axial view: a highintensity mass visible in the infratemporal fossa. (D) MRI (enhanced T1) axial view: gradual contrast effect in the mass. The asterisk marks the lesion in the infratemporal fossa.
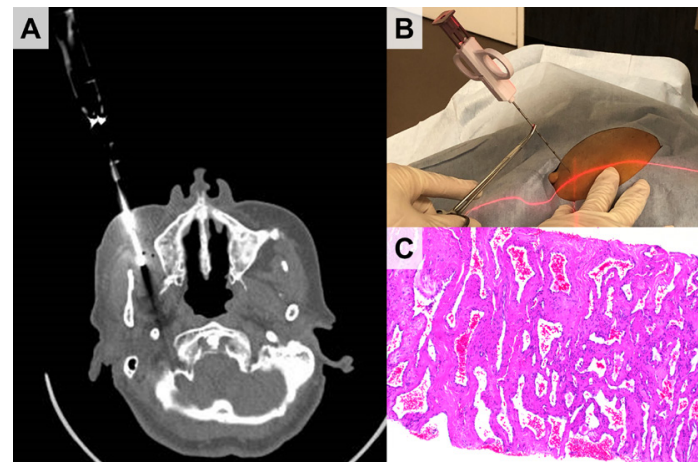

Figure 2 CT-guided core needle biopsy (CNB) for the lesion in the infratemporal fossa. (A) Confirmation of needle insertion with CT. (B) The actual condition of the procedure of CT-guided CNB. (C) Histopathology findings for sample tissue obtained by CNB. Vascular hypertrophy and lumenal accumulation of red blood cells without any noticeable endothelial cell atypia.

hypertrophy and lumenal accumulation of red blood cells (figure 2C). The diagnosis of cavernous haemangioma without any noticeable endothelial cell atypia was made. The patient was followed up without surgery because there were no symptoms associated with the tumour. One year after diagnosis, no obvious symptoms were observed.

CT-guided CNB is a general diagnostic method primarily used for respiratory and digestive organs but can be used on any part of the body such as the head and neck. ${ }^{1}$ CT-guided CNB can accurately approach deep lesions, which are difficult to view with ultrasonography, such as lesions in the deep lobe of the parotid gland, parapharyngeal space and infratemporal fossa.

CNB collects a sufficient amount of tissue compared with fine-needle aspiration cytology and enables immunohistochemical staining, which can diagnose the tumour. CNB helps in the diagnosis of malignant lymphomas, bone and soft tissue tumours, neurogenic tumours and salivary gland tumours. According to a meta-analysis of CNB of head and neck lesions, the most common complication was haematoma $(1 \%, 13$ of 1291 procedures); however, no nerve injuries were reported. ${ }^{2}$ In another systematic review, crude estimates suggested $0.0011 \%$ tumour seeding after CNB. ${ }^{3}$

In the present case, we diagnosed a venous malformation at the infratemporal fossa using a CT-guided CNB. The International Society for the Study of Vascular Anomalies updated in 2014, classified venous malformation as a vascular malformation and a localised abnormality of 
morphogenesis. Vascular malformation in the infratemporal fossa is an extremely rare benign tumour. ${ }^{4}$ When diagnosing vascular malformations, it is important to collect the current medical history and perform ultrasonography and MRI. If the diagnosis is difficult, tissue examination is required. The lesion in the infratemporal fossa was an impalpable tumour, and its boundaries and surrounding tissue were difficult to observe via ultrasonography.

\section{Learning points}

Deep lesions of the head and neck can be difficult to diagnose due to difficulties in the collection of the tissue sample.

- CT-guided core needle biopsy (CNB) can be used on any part of the head and neck area to confirm a diagnosis.

- The lesion in the infratemporal fossa, which is difficult to view with ultrasonography, was diagnosed as a venous malformation using CT-guided CNB without an open biopsy.
CT-guided CNB is very useful in diagnosing lesions of the infratemporal fossa.

Contributors MN examined the patient and diagnosed it. MN and TM wrote the manuscript. MN and TM contribute equally to this work. All authors discussed the results and contributed to the final approval of the manuscript.

Funding The authors have not declared a specific grant for this research from any funding agency in the public, commercial or not-for-profit sectors.

Competing interests None declared.

Patient consent for publication Obtained.

Provenance and peer review Not commissioned; externally peer reviewed.

\section{REFERENCES}

1 Cunningham JD, McCusker MW, Power S, et al. Accessible or inaccessible? diagnostic efficacy of CT-guided core biopsies of head and neck masses. Cardiovasc Intervent Radiol 2015:38:422-9.

2 Novoa E, Gürtler N, Arnoux A, et al. Role of ultrasound-guided core-needle biopsy in the assessment of head and neck lesions: a meta-analysis and systematic review of the literature. Head Neck 2012;34:1497-503.

3 Shah KSV, Ethunandan M. Tumour seeding after fine-needle aspiration and core biopsy of the head and neck--a systematic review. Br J Oral Maxillofac Surg 2016;54:260-5.

4 Nakaya M, Kida W, Ito A, Muneo N, Wataru K, Akiko I, et al. Endoscopic transoral and transmaxillary excision of the infratemporal fossa hemangioma. Auris Nasus Larynx 2015;42:258-62.

Copyright 2021 BMJ Publishing Group. All rights reserved. For permission to reuse any of this content visit

https://www.bmj.com/company/products-services/rights-and-licensing/permissions/

BMJ Case Report Fellows may re-use this article for personal use and teaching without any further permission.

Become a Fellow of BMJ Case Reports today and you can:

- Submit as many cases as you like

- Enjoy fast sympathetic peer review and rapid publication of accepted articles

- Access all the published articles

- Re-use any of the published material for personal use and teaching without further permission

Customer Service

If you have any further queries about your subscription, please contact our customer services team on +44 (0) 2071111105 or via email at support@bmj.com.

Visit casereports.bmj.com for more articles like this and to become a Fellow 